\title{
CHANGES IN THE OXYGEN CONTENT OF HEPATIC VENOUS BLOOD DURING EXERCISE IN PATIENTS WITH RHEUMATIC HEART DISEASE
}

\author{
By J. M. BISHOP, K. W. DONALD, AND O. L. WADE \\ (From The Department of Medicine, University of Birmingham, at the Queen Elizabeth \\ Hospital, Birmingham, England)
}

(Submitted for publication December 27, 1954; accepted March 23, 1955)

In a study of the effect of exercise on the cardiac output of patients with rheumatic heart disease (1) small and frequent samples of mixed venous blood were drawn from the pulmonary artery during a period of leg exercise and subsequent recovery. Thus a continuous record of the oxygen saturation of this blood and of the arterio-venous oxygen content difference ( $\mathrm{A}-\mathrm{V}$ difference) was obtained. In most patients abnormally large A-V differences were found during exercise and in some the mixed venous blood was less than 10 per cent saturated. This low saturation suggested that even were oxygen completely extracted from the blood perfusing the exercising limbs, there must also be a considerable reduction of blood flow to other regions of the body. This possibility has been investigated by following changes in the oxygen saturation of venous blood returning from various regions and organs of the body at rest and during exercise, by taking frequent blood samples through an intravenous catheter.

In this paper, the effect of exercise on the oxygen saturation of hepatic venous blood and on the hepatic arterio-venous oxygen content difference (hepatic A-V difference) in patients with rheumatic heart disease is reported. On the assumption that there is little change in the oxygen uptake of the splanchnic region during brief periods of exercise, alterations in the splanchnic blood flow, inversely related to the changes in the hepatic $\mathrm{A}-\mathrm{V}$ differences, have been inferred.

TABLE I

Clinical details of patients studied

\begin{tabular}{|c|c|c|c|c|c|c|c|}
\hline Patient & Sex & Age & $\underset{(m .2)}{S . A .}$ & Lesions* & Rhythm† & Disability $\ddagger$ & Operative finding \\
\hline $\begin{array}{l}\text { H1 } \\
\text { H2 }\end{array}$ & $\begin{array}{l}\mathbf{F} \\
\mathbf{M}\end{array}$ & $\begin{array}{l}29 \\
19\end{array}$ & $\begin{array}{l}1.65 \\
1.78\end{array}$ & \multirow{5}{*}{$\begin{array}{c}\text { M.S., A.R. } \\
\text { M.S. \& R. } \\
\text { A.R. } \\
\text { M.S. \& R. } \\
\text { A.R. } \\
\text { M.S. } \\
\text { M.S., A.S. } \\
\text { M.S., A.R. } \\
\text { M.S. } \\
\text { M.S. } \\
\text { M.S., A.S. } \\
\text { M.S. } \\
\text { M.S. \& R. } \\
\text { T.R., A.R. } \\
\text { M.S. } \\
\text { Hypertension } \\
\text { M.S. \& R. }\end{array}$} & $\begin{array}{l}\mathbf{S} \\
\mathbf{S}\end{array}$ & $\begin{array}{l}2 \\
3 A\end{array}$ & \multirow{2}{*}{$\begin{array}{l}\text { No operation } \\
\text { Gross mitral } \\
\text { regurgitation } \\
\text { No operation }\end{array}$} \\
\hline H3 & $\mathbf{F}$ & 40 & 1.60 & & $\mathbf{S}$ & 2 & \\
\hline $\begin{array}{l}\text { H4 } \\
\text { H5 } \\
\text { H6 } \\
\text { H7 } \\
\text { H8 } \\
\text { H9 } \\
\text { H10 } \\
\text { H11 }\end{array}$ & $\begin{array}{l}\mathbf{F} \\
F \\
F \\
F \\
F \\
F \\
M \\
M\end{array}$ & $\begin{array}{l}32 \\
43 \\
32 \\
30 \\
34 \\
42 \\
49 \\
26\end{array}$ & $\begin{array}{l}1.55 \\
1.60 \\
1.42 \\
1.54 \\
1.52 \\
1.59 \\
1.60 \\
1.56\end{array}$ & & $\begin{array}{c}\text { S } \\
\text { S } \\
\text { S } \\
\text { S } \\
\text { A.F. } \\
\text { A.F. } \\
\text { A.F. } \\
\text { S }\end{array}$ & $\begin{array}{l}2 \\
3 \mathrm{~A} \\
2 \\
3 \mathrm{~A} \\
3 \mathrm{~B} \\
3 \mathrm{~A} \\
3 \mathrm{~B} \\
3 \mathrm{~B}\end{array}$ & \multirow[t]{2}{*}{$\begin{array}{l}\text { No operation } \\
\text { No operation } \\
\text { No operation } \\
\text { Severe M.S. } \\
\text { Severe M.S. } \\
\text { No operation } \\
\text { Severe M.S. } \\
\text { Slight M.S.; } \\
\text { gross regurgn. } \\
\text { Severe M.S. }\end{array}$} \\
\hline $\mathrm{H} 12$ & $\mathbf{F}$ & 52 & 1.47 & & $\mathbf{S}$ & $3 B$ & \\
\hline H13 & $\mathbf{M}$ & 38 & 1.75 & & A.F. & $3 B$ & $\begin{array}{l}\text { Mod. M.S.; mod. } \\
\text { degree of regurgn. }\end{array}$ \\
\hline H14 & $\mathbf{F}$ & 31 & 1.44 & M.R. & A.F. & $3 B$ & No operation \\
\hline
\end{tabular}

* M.S. Mitral stenosis.

M.R. Mitral regurgitation.

A.R. Aortic regurgitation.

A.S. Aortic stenosis.

T.R. Tricuspid regurgitation.

† S. Sinus rhythm.

A.F. Auricular fibrillation.

$\ddagger$ Disability grade: Modified from American Heart Association grading (1). 
TABLE II

Cardiac output, intravascular pressures and blood oxygen capacities at rest and during exercise

\begin{tabular}{|c|c|c|c|c|c|c|c|c|c|c|c|}
\hline \multirow[b]{2}{*}{ Patient } & & \multirow{2}{*}{$\begin{array}{c}\text { Blood } \\
\text { oxygen } \\
\text { capacity } \\
\text { vol. per cent }\end{array}$} & \multicolumn{2}{|c|}{$\begin{array}{c}\text { Blood oxygen } \\
\text { saturation }\end{array}$} & \multirow[b]{2}{*}{$\begin{array}{l}\text { A-V diff. } \\
\text { ool. } \\
\text { per cent }\end{array}$} & \multirow{2}{*}{$\begin{array}{c}\text { Oxygen } \\
\text { uptake } \\
m l . / m \text { min. }^{2} \\
m . .^{2}\end{array}$} & \multirow{2}{*}{$\begin{array}{c}\text { Cardiac } \\
\text { index } \\
L . / \min . / \\
m . .^{\circ}\end{array}$} & \multicolumn{4}{|c|}{ Pressure $(m m . H g)$} \\
\hline & & & $\begin{array}{l}\text { Mixed } \\
\text { venous } \\
\text { per cent }\end{array}$ & $\begin{array}{l}\text { Arterial } \\
\text { per cent }\end{array}$ & & & & $\begin{array}{l}\text { Mean } \\
\text { P.A. }\end{array}$ & $\begin{array}{l}\text { Mean } \\
\text { P.C.P. }\end{array}$ & $\begin{array}{l}\text { Mean } \\
\text { R.A. }\end{array}$ & $\begin{array}{c}\text { Brachia } \\
\text { artery }\end{array}$ \\
\hline H1 & $\begin{array}{l}\text { Rest } \\
\text { Ex. }\end{array}$ & $\begin{array}{l}19.50 \\
20.50\end{array}$ & $\begin{array}{l}72.0 \\
44.1\end{array}$ & $\begin{array}{l}92.0 \\
91.7\end{array}$ & $\begin{array}{l}3.90 \\
9.76\end{array}$ & $\begin{array}{l}176 \\
573\end{array}$ & $\begin{array}{l}4.51 \\
5.87\end{array}$ & $\begin{array}{l}42 \\
47\end{array}$ & 32 & $\frac{3}{-}$ & 二 \\
\hline $\mathrm{H} 2^{*}$ & $\begin{array}{l}\text { Rest } \\
\text { Ex. }\end{array}$ & $\begin{array}{l}18.44 \\
19.08\end{array}$ & $\begin{array}{l}77.8 \\
47.7\end{array}$ & $\begin{array}{l}96.8 \\
96.8\end{array}$ & $\begin{array}{l}3.52 \\
9.37\end{array}$ & $\begin{array}{l}181 \\
505\end{array}$ & $\begin{array}{l}5.16 \\
5.39\end{array}$ & 二 & 二 & 4 & $100 / 64$ \\
\hline H3 & $\begin{array}{l}\text { Rest } \\
\text { Ex. }\end{array}$ & $\begin{array}{l}19.47 \\
20.11\end{array}$ & $\begin{array}{l}76.8 \\
48.3\end{array}$ & $\begin{array}{l}92.9 \\
93.2\end{array}$ & $\begin{array}{l}3.14 \\
9.03\end{array}$ & $\begin{array}{l}175 \\
544\end{array}$ & $\begin{array}{l}5.58 \\
6.03\end{array}$ & $\begin{array}{l}30 \\
57\end{array}$ & 26 & $\underline{2}$ & $\begin{array}{l}106 / 58 \\
120 / 64\end{array}$ \\
\hline H4 & $\begin{array}{l}\text { Rest } \\
\text { Ex. }\end{array}$ & $\begin{array}{l}17.55 \\
18.76\end{array}$ & $\begin{array}{l}76.4 \\
41.4\end{array}$ & $\begin{array}{l}96.5 \\
97.6\end{array}$ & $\begin{array}{r}3.53 \\
10.54\end{array}$ & $\begin{array}{l}143 \\
701\end{array}$ & $\begin{array}{l}4.04 \\
6.65\end{array}$ & 23 & 12 & 6 & $\begin{array}{l}120 / 66 \\
150 / 72\end{array}$ \\
\hline H5 & $\begin{array}{l}\text { Rest } \\
\text { Ex. }\end{array}$ & $\begin{array}{l}19.17 \\
19.78\end{array}$ & $\begin{array}{l}79.9 \\
47.6\end{array}$ & $\begin{array}{l}94.0 \\
95.0\end{array}$ & $\begin{array}{l}2.71 \\
9.38\end{array}$ & $\begin{array}{l}139 \\
507\end{array}$ & $\begin{array}{l}5.12 \\
5.41\end{array}$ & $\begin{array}{l}18 \\
25\end{array}$ & 二 & 8 & $\begin{array}{l}124 / 76 \\
146 / 84\end{array}$ \\
\hline H6 & $\begin{array}{l}\text { Rest } \\
\text { Ex. }\end{array}$ & $\begin{array}{l}18.70 \\
19.00\end{array}$ & $\begin{array}{l}75.8 \\
43.9\end{array}$ & $\begin{array}{l}95.4 \\
94.8\end{array}$ & $\begin{array}{l}3.74 \\
9.88\end{array}$ & $\begin{array}{l}144 \\
520\end{array}$ & $\begin{array}{l}3.86 \\
5.26\end{array}$ & $\begin{array}{l}23 \\
43\end{array}$ & 20 & 6 & $\begin{array}{l}108 / 74 \\
146 / 84\end{array}$ \\
\hline H7 & $\begin{array}{l}\text { Rest } \\
\text { Ex. }\end{array}$ & $\begin{array}{l}18.85 \\
19.80\end{array}$ & $\begin{array}{l}77.7 \\
51.8\end{array}$ & $\begin{array}{l}97.1 \\
99.2\end{array}$ & $\begin{array}{l}3.66 \\
9.39\end{array}$ & $\begin{array}{l}120 \\
484\end{array}$ & $\begin{array}{l}3.27 \\
5.16\end{array}$ & $\begin{array}{l}33 \\
59\end{array}$ & 24 & $\underline{8}$ & $\begin{array}{l}102 / 62 \\
122 / 78\end{array}$ \\
\hline $\mathrm{H} 8^{*}$ & $\begin{array}{l}\text { Rest } \\
\text { Ex. }\end{array}$ & $\begin{array}{l}14.64 \\
15.40\end{array}$ & $\begin{array}{l}60.1 \\
40.9\end{array}$ & $\begin{array}{l}93.8 \\
97.0\end{array}$ & $\begin{array}{l}4.94 \\
8.62\end{array}$ & $\begin{array}{l}143 \\
423\end{array}$ & $\begin{array}{l}2.89 \\
4.90\end{array}$ & 二 & 二 & - & 112/56 \\
\hline H9 & $\begin{array}{l}\text { Rest } \\
\text { Ex. }\end{array}$ & $\begin{array}{l}20.05 \\
21.30\end{array}$ & $\begin{array}{l}66.0 \\
25.2\end{array}$ & $\begin{array}{l}95.9 \\
96.0\end{array}$ & $\begin{array}{r}6.00 \\
15.08\end{array}$ & $\begin{array}{l}152 \\
630\end{array}$ & $\begin{array}{l}2.53 \\
4.18\end{array}$ & $\begin{array}{l}31 \\
60\end{array}$ & 20 & 11 & $\begin{array}{r}86 / 54 \\
130 / 72\end{array}$ \\
\hline H10 & $\begin{array}{l}\text { Rest } \\
\text { Ex. }\end{array}$ & $\begin{array}{l}18.94 \\
20.70\end{array}$ & $\begin{array}{l}54.5 \\
21.5\end{array}$ & $\begin{array}{l}89.5 \\
87.7\end{array}$ & $\begin{array}{r}6.62 \\
13.68\end{array}$ & $\begin{array}{l}144 \\
435\end{array}$ & $\begin{array}{l}2.18 \\
3.18\end{array}$ & $\begin{array}{l}50 \\
80\end{array}$ & 36 & 1 & - \\
\hline H11 & $\begin{array}{l}\text { Rest } \\
\text { Ex. }\end{array}$ & $\begin{array}{l}17.94 \\
18.29\end{array}$ & $\begin{array}{l}56.3 \\
21.4\end{array}$ & $\begin{array}{l}92.5 \\
93.1\end{array}$ & $\begin{array}{r}6.49 \\
13.11\end{array}$ & $\begin{array}{l}183 \\
410\end{array}$ & $\begin{array}{l}2.83 \\
3.12\end{array}$ & $\begin{array}{l}78 \\
90\end{array}$ & 32 & $\underline{8}$ & $\begin{array}{l}112 / 78 \\
120 / 88\end{array}$ \\
\hline H12 & $\begin{array}{l}\text { Rest } \\
\text { Ex. }\end{array}$ & $\begin{array}{l}18.80 \\
20.03\end{array}$ & $\begin{array}{l}69.4 \\
32.2\end{array}$ & $\begin{array}{l}96.0 \\
95.5\end{array}$ & $\begin{array}{r}5.00 \\
12.68\end{array}$ & $\begin{array}{l}169 \\
405\end{array}$ & $\begin{array}{l}3.37 \\
3.19\end{array}$ & $\begin{array}{l}57 \\
80\end{array}$ & 31 & $\underline{5}$ & $\begin{array}{l}220 / 100 \\
265 / 152\end{array}$ \\
\hline H13 & $\begin{array}{l}\text { Rest } \\
\text { Ex. }\end{array}$ & $\begin{array}{l}21.02 \\
21.80\end{array}$ & $\begin{array}{l}54.4 \\
19.1\end{array}$ & $\begin{array}{l}94.7 \\
97.0\end{array}$ & $\begin{array}{r}8.47 \\
16.98\end{array}$ & $\begin{array}{l}151 \\
545\end{array}$ & $\begin{array}{l}1.79 \\
3.21\end{array}$ & $\begin{array}{l}29 \\
60\end{array}$ & 19 & 8 & - \\
\hline H14 & $\begin{array}{l}\text { Rest } \\
\text { Ex. }\end{array}$ & $\begin{array}{l}23.46 \\
24.10\end{array}$ & $\begin{array}{l}61.3 \\
22.0\end{array}$ & $\begin{array}{l}94.7 \\
95.2\end{array}$ & $\begin{array}{r}7.84 \\
17.64\end{array}$ & $\begin{array}{l}146 \\
492\end{array}$ & $\begin{array}{l}1.86 \\
2.79\end{array}$ & $\begin{array}{l}36 \\
40\end{array}$ & 23 & 8 & - \\
\hline
\end{tabular}

* In patients $\mathrm{H} 2$ and $\mathrm{H} 8$ mixed venous blood was sampled from the right atrium.

\section{METHOD}

Fourteen patients suffering from rheumatic heart disease, mainly involving the mitral valve, were studied. Patient $\mathrm{H} 12$ also had benign hypertension. All patients were under consideration for the operation of mitral valvotomy and their principal clinical features are summarized in Table I. Each study was carried out six hours after the last meal, preparation following the routine described in previous communications $(1,2)$. After the catheter tip had been introduced into the pulmonary artery and an indwelling needle inserted in the brachial artery, the usual pressure recordings were made and a measurement of the resting cardiac output carried out. The patient then exercised in the supine position on a variable load constant speed bicycle ergometer to a de- gree near to his tolerance level. Exercise was continued for five minutes in most instances, although five patients were unable to complete this period in the first exercise study owing to dyspnea or weakness. Patient $\mathrm{H} 10$, who had previously suffered an embolism of a major artery of the leg, was forced to stop after $33 / 4$ minutes owing to ischemic muscle pain. Measurements of brachial and pulmonic arterial pressures were made throughout exercise and recovery and the cardiac output was measured during the fifth or last minute of exercise in which three samples of arterial and of mixed venous blood were taken and the expired air was collected in a Tissot spirometer, through which expired air had been passing during the earlier minutes of exercise. The validity of such measurements of cardiac output has been previously studied (1). 
After the pulmonary artery pressure had returned to resting levels, the catheter was manipulated until its tip lay well in the hepatic vein. Care was taken to ensure that the tip was not impacted and that there were no redundant loops of catheter lying within the right atrium or elsewhere. With these precautions, sampling was possible throughout the subsequent exercise without the catheter becoming displaced from the hepatic vein. Since the hepatic veins join the inferior vena cava separately it is not possible to obtain mixed hepatic venous blood. In the studies here reported, all samples were obtained from the middle of the right lobe of the liver. Bradley (3) has shown that there is relatively uniform extraction of bromsulphthalein from the blood by different areas of the liver and it would appear justifiable to assume that the blood sampled as described was representative of mixed hepatic venous blood.

Thirty minutes after the end of the period of exercise during which cardiac output had been measured, two or three samples of blood were drawn from the catheter in the hepatic vein over a period of one or two minutes. The patient then carried out a second period of exercise, the same degree of work being performed. Most of the patients exercised for five minutes but patients $H 7$ and H10 only completed four minutes, while patients $\mathrm{H} 2, \mathrm{H} 3$, and $\mathrm{H} 11$ exercised for ten minutes. One to three blood samples were drawn from the catheter each minute throughout exercise, the time of each sample being noted.
Sampling was continued during the recovery period but at a slower rate after the first two or three minutes and was continued during twenty or more minutes of recovery in some patients. Samples of arterial blood were also taken during exercise and recovery in the majority of patients. The position of the catheter tip was checked at the end of the study, although this precaution was omitted in the case of patients H5 and H12.

All blood samples were collected in lightly oiled all glass syringes with heparin filled dead space. A little mercury was then drawn into each syringe which was sealed with a hub cap, shaken and placed on a rotating drum. The percentage oxygen saturation was estimated in duplicate by a spectrophotometric method previously described (4). The blood oxygen capacity at rest and during exercise was estimated by the manometric method of Van Slyke and Neill on blood that had been rotated in a sealed flask in contact with air for fifteen minutes.

Expired air was analyzed by the Scholander micromethod, duplicate analyses being required to check to within 0.03 per cent.

\section{RESULTS}

The results of the measurements of cardiac output at rest and on exercise, together with the blood oxygen capacities are given in Table II.

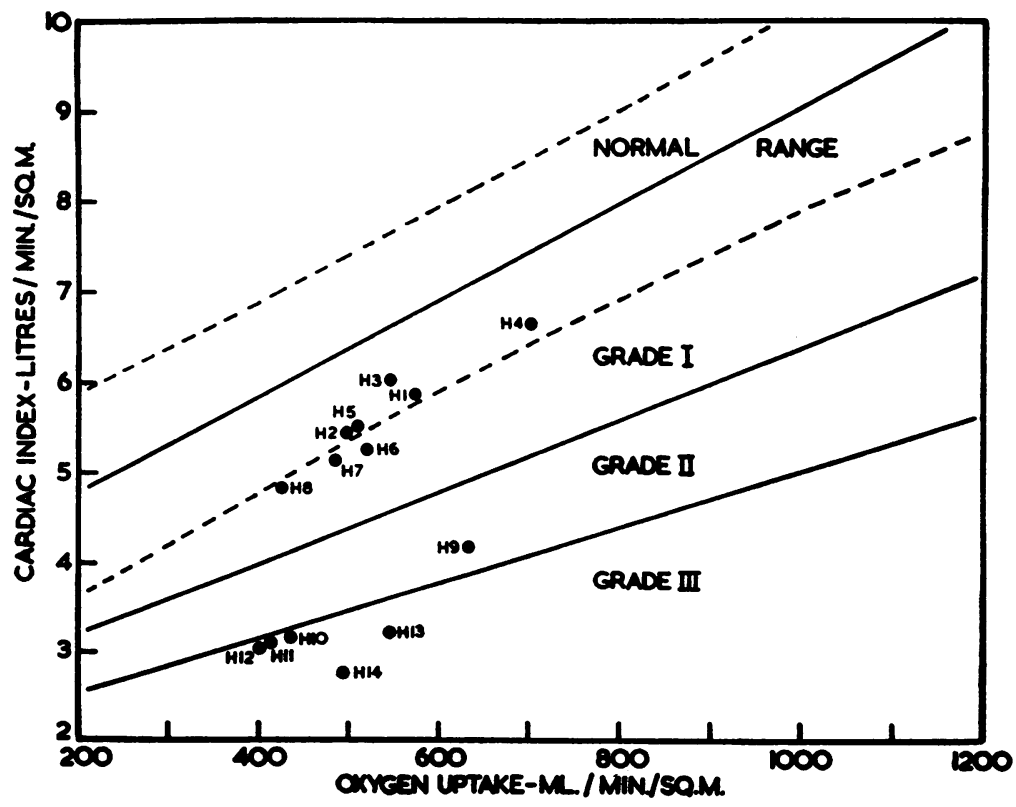

Fig. 1. Oxygen Uptake and Cardiac Index during Exercise in 14 Patients with Rheumatic Heart Disease

The regression line obtained in a previous study from 48 observations on 16 normal subjects is shown together with the 95 per cent confidence limits. Values obtained within the three arbitrarily delineated zones are described as Grades I, II, and III impairment of exercising cardiac output response. 


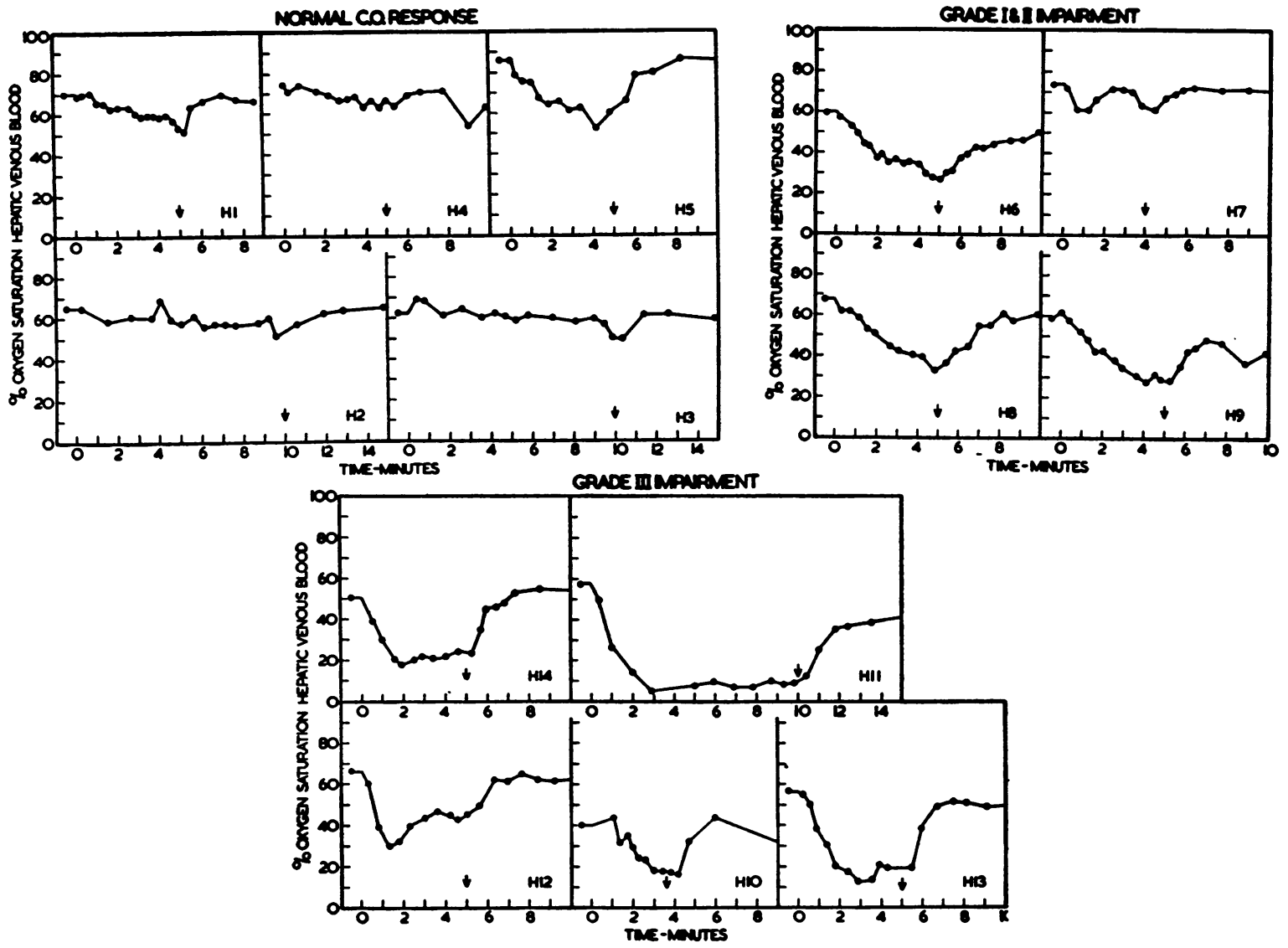

Fig. 2. Hepatic Venous Blood Oxygen Saturation during Exercise and Recovery

Exercise commenced at time 0 , before which resting values are shown, and ceased at the signal.

The resting and exercise brachial arterial and pulmonary arterial pressure, and the resting pulmonary 'capillary' and right atrial pressures are also given.

Figure 1 illustrates the regression line relating cardiac index to oxygen uptake derived from a previous study of the effect of exercise in normal subjects (2). Its 95 per cent confidence limits are shown by interrupted lines. Three arbitrary zones below the normal range have been delineated and the response of the cardiac output to exercise of each patient here studied is plotted and impairment of response can be conveniently described as Grade I, II, or III.

\section{The Oxygen Saturation of Hepatic Venous Blood} at Rest and During Exercise and Recovery

The hepatic venous oxygen saturation of each patient is plotted at rest and during each minute of exercise and the first five minutes of recovery in Figure 2. Changes in arterial oxygen saturation are not shown in this figure, but the resting and exercising values are given in Table II. Some patients were studied during longer periods of recovery than is shown in Figure 2 and details of these findings are given in Table III. The results are considered in four groups according to the grade of the response of the cardiac output of each patient to exercise.

\section{Normal cardiac output response to exercise}

Five patients $(\mathrm{H} 1, \mathrm{H} 2, \mathrm{H} 3, \mathrm{H} 4$, and $\mathrm{H} 5)$ fell within this group. The resting hepatic venous saturation in the first four of these patients was 70 per cent, 65 per cent, 67 per cent, and 76 per cent, respectively, although in patient $\mathrm{H} 3$ one value at a much lower level was obtained. The fifth patient, $\mathrm{H} 5$, had a considerably higher and 


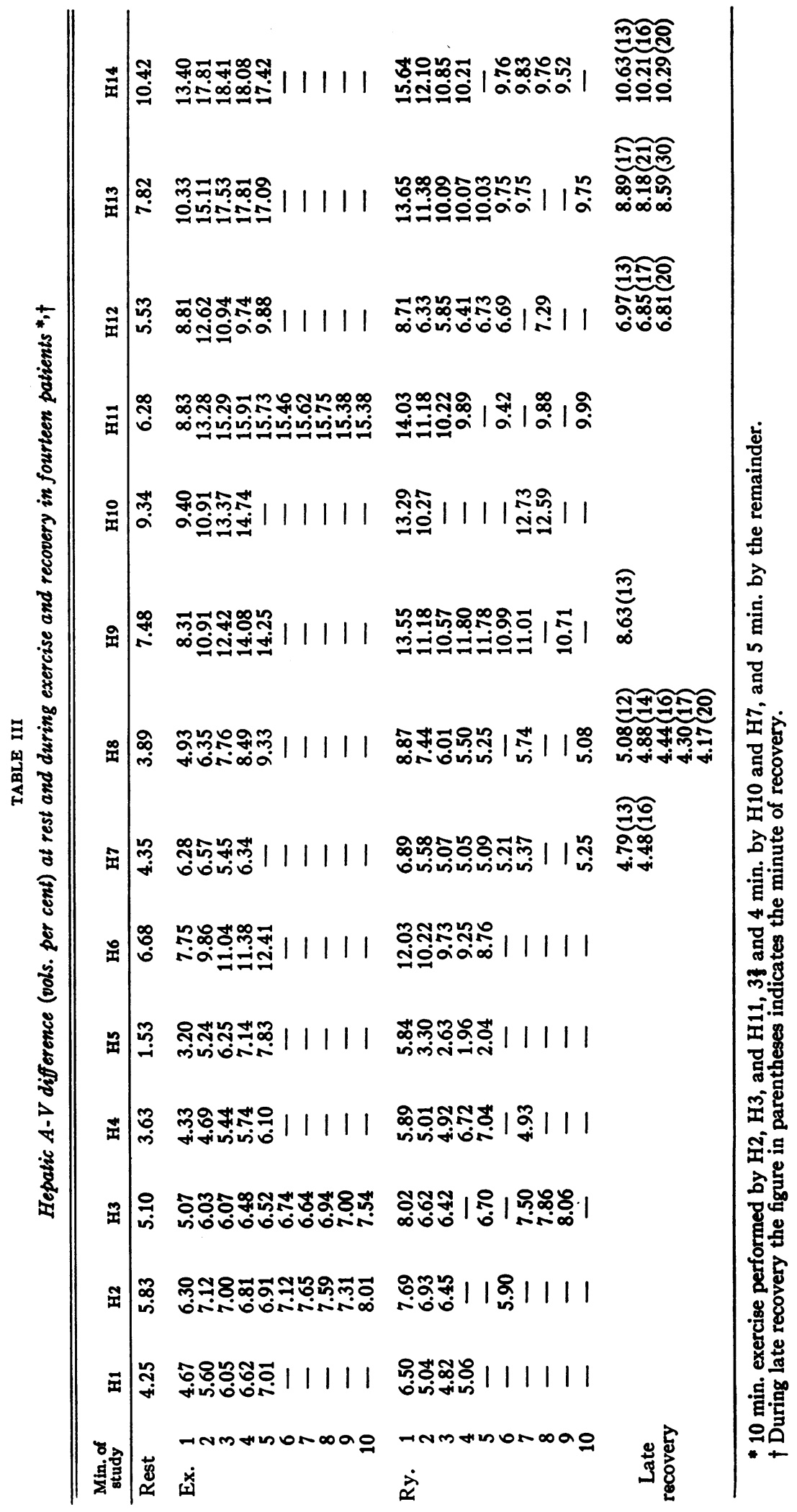


abnormal resting saturation of 86 per cent. (Normal range 56 per cent to 83 per cent : Bradley, Ingelfinger, and Bradley [5].)

During the first minute of exercise, there was little change in hepatic venous oxygen saturation except in patient $\mathrm{H} 5$, in whom a prompt fall occurred. A reduction of saturation was evident in all patients after the first minute and this was in general greater during the second and third minutes than in subsequent minutes. A further and steeper reduction of oxygen saturation was noted in patients $\mathrm{H} 1, \mathrm{H} 2, \mathrm{H} 3$, and $\mathrm{H} 5$ during the last minute of exercise. This fall averaged 9 per cent and was continued into the first half minute of recovery in two patients but not in the remaining two. Although the reduction of hepatic venous oxygen saturation was small in patients $\mathrm{H} 2, \mathrm{H} 3$, and $\mathrm{H} 4$, a more marked change was seen in patient $\mathrm{H} 1$ and a still greater fall occurred in patient H5. Nevertheless, the lowest levels attained during exercise, expressed as the mean saturation during a minute, were strikingly similar; 58 per cent, 55 per cent, 56 per cent, 65 per cent, and 57 per cent in patients $\mathrm{H} 1, \mathrm{H} 2, \mathrm{H} 3, \mathrm{H} 4$, and $\mathrm{H} 5$, respectively.

There was a prompt increase of hepatic venous oxygen saturation when exercise ceased, a brief delay being observed in only two patients, $\mathrm{H} 1$ and H3. Recovery to resting levels was achieved completely, or within 2 per cent, by the second or third minute in all but patient $\mathrm{H} 3$. In this patient the saturation remained 6 per cent below resting values during the second and third minute of recovery and subsequently fell further, reaching its lowest value eleven minutes after exercise ceased. In patient $\mathrm{H} 4$ also, a second reduction of hepatic venous saturation occurred during recovery.

\section{Grade I impairment of exercise cardiac output}

Three patients showed this grade of cardiac output impairment, (H6, H7, and H8). In them, the resting hepatic venous oxygen saturation was 60 per cent, 74 per cent, and 67 per cent, respectively. On exercise there was no delay in the onset of reduction of saturation comparable to that found in the patients with a normal cardiac output response to exercise, although patient $\mathrm{H} 8$ showed only a small fall during the first minute. The fall of saturation continued throughout exercise in patients $\mathrm{H} 6$ and $\mathrm{H} 8$, reaching the lowest minute mean levels of 30 per cent and 37 per cent, respectively, at the end of exercise. The behavior in patient $\mathrm{H} 7$ differed considerably in that, following a steep fall of percentage saturation in the first minute of exercise, an increase of saturation followed in the second minute and a level but little below the resting value was maintained during the third minute. During the fourth and last minute of exercise a further fall occurred but the lowest level reached during exercise was only 61 per cent.

When exercise ceased, the increase in blood oxygen saturation was prompt in onset, there being a brief delay in patient $\mathrm{H} 7$. In this patient the saturation which had decreased little on exercise returned to within 2 per cent of its resting value by the third minute of recovery after which a further slight fall occurred. In patients $\mathrm{H} 6$ and $\mathrm{H8}$, although the initial rate of recovery was rapid, it became slower after two and three minutes, respectively, and in the third minute of recovery the hepatic venous blood oxygen saturation remained 15 per cent and 8 per cent below the resting level. Recovery was complete in patient $\mathrm{H} 8$ by the twentieth minute but the study was not prolonged beyond the fifth minute in patient $\mathrm{H} 6$ at which time recovery was still incomplete.

\section{Grade II impairment of exercise cardiac output}

Only one patient, H9, fell within this grading. After a very brief delay at the onset of exercise, the hepatic venous blood oxygen saturation fell from the resting value of 59 per cent, and, during the last minute of exercise, a steady level around 30 per cent saturation was maintained.

Recovery after exercise was rapid and, by the end of the second minute of recovery, a value only 10 per cent below the resting level had been reached. Thereafter, the percentage saturation fell and rose again, but, even after twelve minutes of recovery, remained somewhat below the resting value.

\section{Grade III impairment of exercise cardiac output}

Five patients, H10, H11, H12, H13, and H14 showed this marked impairment of response of cardiac output to exercise. The hepatic venous 
blood oxygen saturations at rest were 40 per cent, 58 per cent, 67 per cent, 58 per cent, and 50 per cent, respectively. There was a prompt fall of saturation at the commencement of exercise except in patient $H 10$, in whom no fall was seen until after the first minute of exercise. The fall was more rapid than in the patients in previous groups and the lowest level was reached after $11 / 4$ to 3 minutes of exercise. A rise of saturation then occurred in three of these patients even though exercise was continuing. This rise was relatively small in patients $\mathrm{H} 13$ and $\mathrm{H} 14$ but was considerable in patient $\mathrm{H} 12$ where the mean level in the fifth and last minute was 12 per cent higher than in the second minute of exercise when the lowest saturation was reached.

The lowest minute mean oxygen saturation levels reached were 18 per cent, 6 per cent, 32 per cent, 15 per cent, and 21 per cent in patients $\mathrm{H} 10, \mathrm{H} 11, \mathrm{H} 12, \mathrm{H} 13$, and $\mathrm{H} 14$, respectively. The level reached in patient $\mathrm{H} 11$ is particularly noteworthy, the hepatic venous blood oxygen saturation remaining constant between 6 per cent and 10 per cent from the third to the tenth and last minute of exercise.

When exercise ceased an increase in saturation occurred rapidly in two patients and after a delay of 20 to 30 seconds in the remaining three. Three minutes after exercise had ceased, saturation had reached its resting level in patient $\mathrm{H} 10$, was still 3 per cent and 7 per cent below resting in patients $\mathrm{H} 12$ and $\mathrm{H} 13$, and was slightly higher than resting in patient $H 14$. In patients $H 10$, $\mathrm{H} 12$, and $\mathrm{H} 13$ there was a subsequent fall in saturation. In $\mathrm{H} 10$ it was still 10 per cent below its resting level in the eighth minute of recovery when the study terminated and in $\mathrm{H} 12$ it was still 5 per cent below resting level by the twenty-first minute of recovery, but by this time the resting level had been regained in H13. In patient H11 saturation was 20 per cent below its resting value after three minutes of recovery and it remained at this level until the tenth minute when the study ended.

\section{Hepatic and mixed venous blood saturation}

The average lowest mean value of oxygen saturation of hepatic venous blood found in any minute during exercise in the group with a normal re- sponse of cardiac output was 60 per cent. In the group with Grade I impairment of response it was 44 per cent, in the one patient with Grade II impairment it was 29 per cent, and in the group with Grade III impairment it was 18 per cent.

When the oxygen saturations of blood in the pulmonary artery and hepatic vein were compared in each patient during similar degrees of exercise, it was found that patients with a normal response of cardiac output to exercise showed less unsaturation of hepatic venous blood than of mixed venous blood (mean in hepatic vein, 60 per cent; mean in pulmonary artery, 46 per cent). In the case of two of the three patients with Grade I impairment of response and all five patients with Grade III impairment the reverse was true, the percentage oxygen saturation of mixed venous blood being equal to or higher than that of hepatic venous blood during exercise. In the patients with Grade III impairment the mean oxygen saturation of mixed venous blood was 23 per cent and of hepatic venous blood was 18 per cent.

\section{Hepatic arterio-venous oxygen content difference at rest}

The area between the curves obtained when the arterial and hepatic venous oxygen saturation were plotted against time and thus the mean saturation difference for each minute, could be determined from any of the individual studies illustrated in Figure 2. Since the blood oxygen ca-

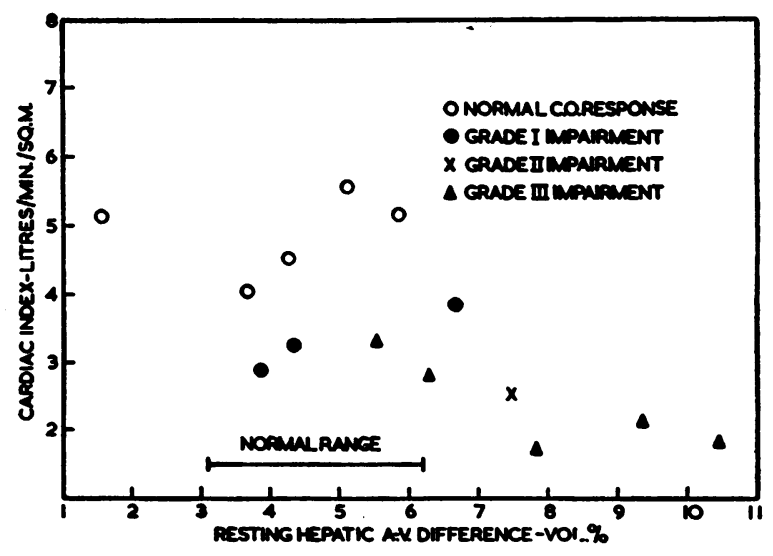

Fig. 3. Hepatic A-V Dimference and Cardiac Index at Rest in 14 Patients with Rheumatic Heart Disease

The normal range of resting hepatic $A-V$ difference shown is that found by Myers, Brannon, and Holland (6). 


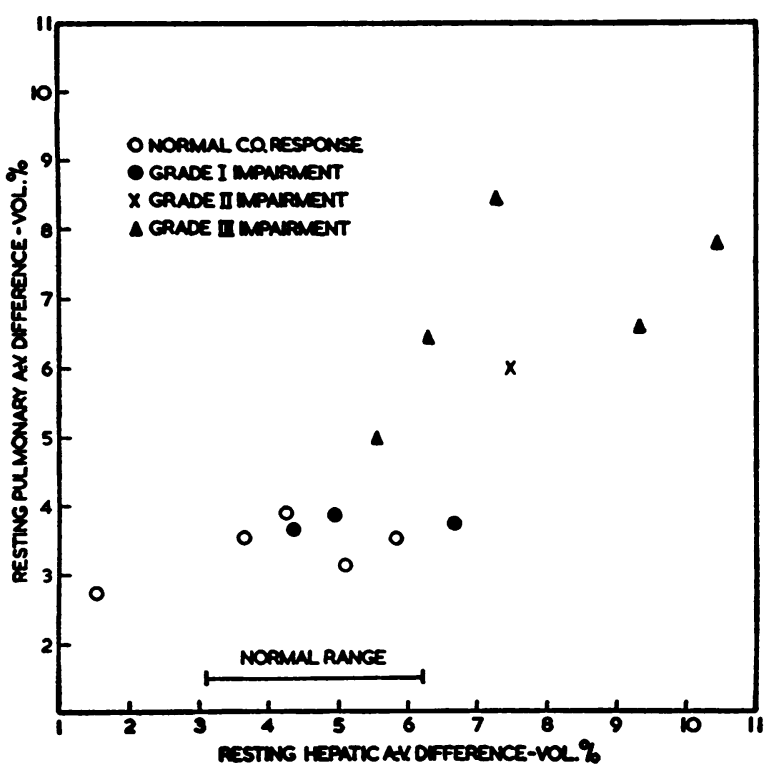

Fig. 4. Hepatic A-V Difference and 'Pulmonary A-V Difference' at Rest in 14 Patients with RheUmatic Heart Disease

The normal range of resting hepatic $A-V$ difference shown is that found by Myers, Brannon, and Holland (6).

pacity was known, the mean hepatic arterio-venous oxygen content difference (hepatic A-V difference) could be calculated, not only in the resting state, but during each minute of exercise and recovery. These results are given in Table III.

In Figure 3 the hepatic $A-V$ difference of each patient at rest is plotted against the resting cardiac index. There is a rough linear relationship, low cardiac output in the more disabled patients being associated with a large hepatic A-V difference. In the four patients in whom the resting cardiac index was $2.5 \mathrm{~L}$. per min. per $\mathrm{m}^{2}$. or less, the hepatic $\mathrm{A}-\mathrm{V}$ differences were abnormally large. (H9, 7.5 vol. per cent; H10, 9.3 vol. per cent; H13, 7.8 vol. per cent; H14, 10.4 vol. per cent.) The range of normal hepatic A-V difference found by Myers, Brannon, and Holland ( 6 ) is 3.1 to 6.2 vol. per cent (49 subjects).

In Figure 4 the hepatic A-V difference for each patient is plotted against the arterial-mixed venous blood oxygen content difference (described as 'pulmonary A-V difference' for convenience). In six patients the hepatic A-V difference and pulmonary $\mathrm{A}-\mathrm{V}$ difference were approximately equal, while in a further six patients the hepatic $\mathrm{A}-\mathrm{V}$ difference exceeded the pulmonary A-V dif- ference by an average of more than 2.0 vol. per cent. The hepatic A-V difference was markedly less than the pulmonary $A-V$ difference in only two patients and one of these had an abnormally small hepatic $\mathrm{A}-\mathrm{V}$ difference.

\section{Hepatic arterio-venous oxygen content difference during exercise}

Figure 5 shows the hepatic A-V difference plotted against the total minute oxygen uptake at rest and during exercise, the two points being joined in each case. The exercise hepatic $A-V$ difference plotted is the maximum mean minute value achieved up to the fifth minute of the second period of exercise. The oxygen uptake determined during the first and comparable period of exercise, is taken as a measure of the work performed. In the patients with a normal response of cardiac output to exercise, the hepatic A-V difference increased slightly with exercise just exceeding the upper limits of the normal resting range. A great increase occurred in the patients with Grade III impairment of response of cardiac output although they performed similar or only slightly less exercise. Patients with Grade I and II impairment of response occupy an intermediate position.

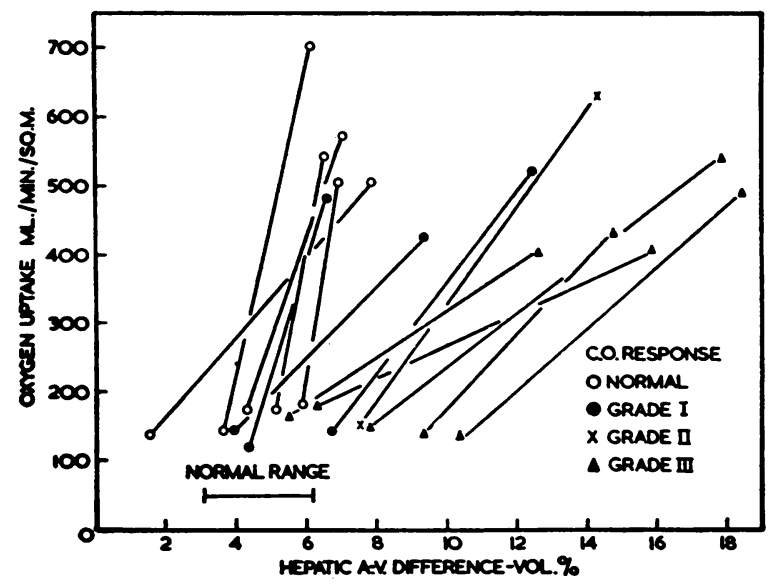

Fig. 5. Hepatic A-V Difference and Total Oxygen Uptake at Rest and During Exercise in 14 Patients with Rheumatic Heart Disease

The hepatic $A-V$ difference during exercise is the greatest value observed up to the fifth minute of exercise, and the two points are joined in each patient studied. The normal range of resting hepatic $A-V$ difference shown is that found by Myers, Brannon, and Holland (6). 
Recovery of hepatic $A-V$ difference after exercise

The studies during recovery are less adequate than those during exercise as the period of continued sampling varied considerably and the greater intervals between sampling makes interpretation less certain.

The hepatic $\mathrm{A}-\mathrm{V}$ difference had returned to the resting value by the second or third minute in three of the patients $(\mathrm{H} 1, \mathrm{H} 2$, and $\mathrm{H} 5)$ with a normal cardiac output response to exercise. The remaining patients in this group ( $\mathrm{H} 3$ and $\mathrm{H} 4$ ) had values which still exceeded the resting hepatic $\mathrm{A}-\mathrm{V}$ difference in the ninth and seventh minutes of recovery, respectively.

In the patients with Grade III impairment recovery was slower except in patient $\mathrm{H} 14$ in whom it was complete by the third minute. The most striking delay in recovery was in patient $\mathrm{H} 11$ in whom, after ten minutes, the hepatic $\mathrm{A}-\mathrm{V}$ difference was still more than 3.0 vol. per cent in excess of the resting value. The hepatic A-V difference was greater than at rest until the seventeenth minute of recovery in patient $\mathrm{H} 13$, until the twentieth minute in patient $\mathrm{H} 12$ and until the seventh minute in patient $\mathrm{H} 10$, when the study ceased. Recovery was delayed similarly in the four patients with Grade I and II impairment of response of cardiac output.

To summarize, it appears that, while in some patients with a normal response of cardiac output to exercise the hepatic A-V difference returns to resting levels within three minutes, this is not a constant feature. In patients with an impaired exercise cardiac output, especially when this impairment is severe, delay in recovery is present in almost every case and is prolonged to the tenth, and in some patients the twentieth minutes.

\section{Deductions as to changes in hepatic blood flow}

The increase in $\mathrm{A}-\mathrm{V}$ difference in a region where it is unlikely that the oxygen uptake altered greatly during the period under consideration, makes it probable that there was a corresponding reduction in blood flow through that region. If the oxygen uptake of the splanchnic region is assumed to remain constant, then the exercise flow may be expressed as a percentage of the flow at rest. For:

$$
F_{E}=F_{R} \times \frac{A V_{R}}{A V_{E}} \times 100
$$

where $F_{E}$ and $F_{R}$ are the exercising and resting hepatic blood flows and $A V_{\mathbf{E}}$ and $A V_{\mathbf{R}}$ the corresponding hepatic $A-V$ differences.

In Figure 6 the hepatic blood flow during exercise calculated in this way and expressed as a percentage of the patient's resting hepatic flow, is plotted against minute oxygen uptake during exercise. In general the patients with a normal response of cardiac output to exercise show the least reduction of hepatic blood flow. The mean exercising hepatic flow is 59 per cent of the resting flow in this group, as compared with 50 per cent of the resting flow in the patients with Grade III impairment of cardiac output response to exercise. If however these calculations exclude patient $\mathrm{H} 5$ whose resting hepatic $\mathrm{A}-\mathrm{V}$ difference was abnormally small, the mean hepatic blood flow during exercise for the group of patients with normal response of cardiac output was 71 per cent of the resting flow (Table IV).

TABLE TV

Hepatic $A-V$ difference at rest and on exercise and deduced changes in hepatic blood flow *

\begin{tabular}{|c|c|c|c|c|c|c|}
\hline & \multicolumn{3}{|c|}{$\begin{array}{l}\text { Normal C.O. response } \\
\text { (Mean Oz uptake } 581 \text { ml./min./m. } \\
\text { (Patient H5 excluded) }\end{array}$} & \multicolumn{3}{|c|}{$\begin{array}{l}\text { Grade III impairment of C.O. response } \\
\left.\left.\text { (Mean } \mathrm{O}_{2} \text { uptake } 457 \mathrm{ml} . / \mathrm{min} . / \mathrm{m} .\right)^{\prime}\right)\end{array}$} \\
\hline & \multirow[b]{2}{*}{$\begin{array}{l}\text { A-V } \\
\text { diff. } \\
\text { Vol. \% }\end{array}$} & \multicolumn{2}{|c|}{ Hepatic blood flow } & \multirow[b]{2}{*}{$\begin{array}{c}\text { A-V } \\
\text { diff. } \\
V o l . \% \\
\end{array}$} & \multicolumn{2}{|c|}{ Hepatic blood flow } \\
\hline & & $\begin{array}{l}\text { (a) } \\
\text { As percentage } \\
\text { resting } \\
\text { flow }\end{array}$ & $\begin{array}{l}\text { (b) } \\
\text { As percentage } \\
\text { "mean normal } \\
\text { resting flow" }\end{array}$ & & $\begin{array}{l}\text { (a) } \\
\text { As percentage } \\
\text { reating } \\
\text { flow }\end{array}$ & $\begin{array}{l}\text { (b) } \\
\text { As percentage } \\
\text { "mean normal } \\
\text { resting flow" }\end{array}$ \\
\hline Rest & 4.70 & 100 & 91 & 7.88 & 100 & 54 \\
\hline Exercise & 6.64 & 71 & 65 & 15.90 & 50 & 27 \\
\hline
\end{tabular}

* Mean values for group with normal cardiac output response to exercise and group with Grade III impairment of exercise cardiac output. 


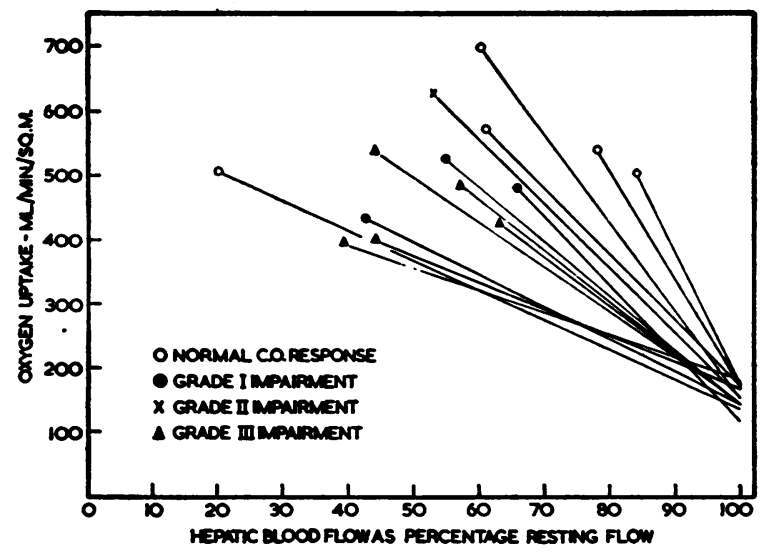

Fig. 6. Hepatic Blood Flow as a Percentage of Resting Flow and Total Body Oxygen Uptake, at Rest and during Exercise, in 14 Patients with RheUmatic Heart Disease

Resting and exercise values in each patient studied are joined.

Since there was considerable variation in resting hepatic A-V differences, many of the values observed being abnormal, a better estimation of the absolute changes in blood flow may be obtained by using, instead of each patient's resting hepatic $\mathrm{A}-\mathrm{V}$ difference, a mean resting hepatic $\mathrm{A}-\mathrm{V}$ difference derived from normal subjects. In the largest study of normal subjects yet reported, Myers, Brannon, and Holland (6) obtained a mean resting hepatic $\mathrm{A}-\mathrm{V}$ difference of $4.29 \mathrm{vol}$. per cent. Since Myers and Hickam (7) found that the splanchnic oxygen uptake in a group of resting patients in frank congestive cardiac failure was not significantly altered from normal (mean, $41 \mathrm{ml}$. per min. per $\mathrm{m}^{2}{ }^{2}$ : normal mean, $38 \mathrm{ml}$. per min. per $\mathrm{m}^{2}$ ), it can be assumed that the resting splanchnic oxygen uptake of the patients here studied was also equal to the mean normal resting value. Thus the resting hepatic blood flow can be expressed as a percentage of the mean resting hepatic blood flow of normal subjects. For:

$$
F_{R}=F_{M N R} \times \frac{4.29}{A_{R}} \times 100
$$

where $F_{R}$ is the patient's resting hepatic blood flow, $\mathrm{AV}_{\mathbf{B}}$ his resting hepatic $\mathrm{A}-\mathrm{V}$ difference and $F_{\text {YNR }}$ is the mean normal resting hepatic blood flow. If it is further assumed that the splanchnic oxygen uptake of the patients was unaltered by exercise, the hepatic blood flow on exercise can

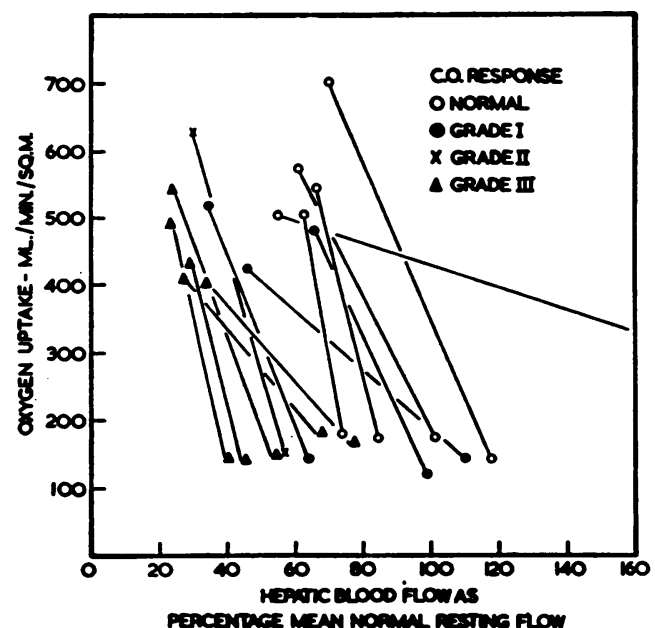

Fig. 7. Hepatic Blood flow as a Percentage of mean Normal Resting Flow and Total Oxygen Uptake, at Rest and during Exercise, in 14 Patients with Rheumatic Heart Disease

The two points are joined in each patient studied.

also be derived as a percentage of the mean normal resting hepatic flow by the same relationship.

The values for all patients at rest and on exercise obtained by making these assumptions are shown in Figure 7, the two points for each patient being joined. Mean values for the group with normal response of cardiac output to exercise, again omitting patient $\mathrm{H} 5$, and for the group with Grade III impairment of response of cardiac output are given in Table IV. In the group with a normal response the resting hepatic blood flow fell from 91 per cent of the mean resting flow of normal subjects to 65 per cent of this flow when they exercised. The patients with Grade III impairment of response had a resting hepatic blood flow that was only 54 per cent of the normal resting flow and on exercise the flow fell to 27 per cent of the normal resting flow.

\section{DISCUSSION}

Although it has been widely accepted and taught that there is a reduction in splanchnic blood flow during exercise, there is little convincing evidence in support of this. Barcroft and Florey (8) observed contraction of the exteriorized spleen in dogs during exercise together with very transient blanching of a part of exteriorized colon. Herrick, Grindley, Baldes, and Mann (9) ap- 
plied thermostromuhrs to the superior mesenteric and splenic arteries of dogs. There was an increased blood flow on exercise in both arteries in the majority of their studies, although in a number there was a reduction immediately after exercise. The accuracy of the thermostromuhr technique has been severely criticized (10) and these results must be treated with considerable reserve. Bradley (11), in preliminary experiments using the bromsulphthalein method over longer periods of rest and exercise in a normal human subject, obtained evidence suggesting that there was a reduction in splanchnic blood flow during exercise.

In the present investigation it has been shown that profound and rapid changes in the hepatic $\mathrm{A}-\mathrm{V}$ difference occurred in patients with rheumatic heart disease during leg exercise in the supine position and that these changes were greater in patients with severe limitation of cardiac output response to exercise. Unless there were quite extraordinary and unexpected increases in splanchnic oxygen uptake during exercise, this suggests that the hepatic blood flow of these patients, which was already considerably reduced at rest, was still further reduced during exercise to about one quarter of the normal resting flow. Thus on the basis of a mean normal resting hepatic blood flow of $1530 \mathrm{ml}$. per min., as determined by Bradley, Ingelfinger, and Bradley (5), the hepatic blood flow during exercise in the patients with a normal cardiac output response was of the order of 1 liter per min. Similarly, the patients with Grade III impairment of cardiac output had a mean resting flow of about $800 \mathrm{ml}$. per min. which fell on exercise to approximately $400 \mathrm{ml}$. per min. These findings at rest in the patients with Grade III impairment are in close agreement with the results of Myers and Hickam (7) whose patients were in congestive failure.

If on exercise this reduction in blood flow to non-exercising parts of the body did not occur in these patients with low unchanging cardiac outputs, then the maintenance of the blood pressure (see Table II) in the presence of considerable vasodilation in the legs, and of adequate blood supply and oxygen transport to the exercising muscles would not be possible.

The changes in hepatic A-V oxygen difference during exercise in normal subjects are not known but, in view of the definite increase of $A-V$ oxy- gen difference during exercise in patients with rheumatic heart disease and normal behavior of the cardiac output during exercise, it seems probable that the same change in A-V oxygen difference occurs in normal subjects. Studies in normal subjects are in progress.

The low levels of oxygen saturation of blood in the hepatic venous system during exercise in the more disabled patients indicate that parts of the liver, in particular the centrilobular cells, must be subjected to very low oxygen tensions during exercise. Since recovery to resting levels was very prolonged in a number of these patients, the oxygen tensions in the centrilobular cells must have been abnormally low for considerable periods of time. Centrilobular necrosis is a well recognized result of anoxia (12) and it has also been shown that recurrent attacks of minor centrilobular necrosis may lead to fibrosis. The degree of exertion in these experiments, which did not cause dyspnea in many cases, must be paralleled not infrequently in the everyday life of these patients. It would appear possible, therefore, that many of the more disabled patients with heart disease suffer from repeated, marked and prolonged reduction of splanchnic blood flow and that this may play a part in the causation of the disturbances of liver structure and function found in a number of such patients.

\section{SUMMARY}

The changes in oxygen saturation of hepatic venous blood have been followed by frequent catheter sampling during and after leg exercise in patients with rheumatic heart disease.

The hepatic oxygen A-V differences were found to increase in all patients during exercise, the increase being greatest in the patients in whom the response of the cardiac output to exercise was impaired. In some of these disabled patients when exercise ceased the return of the hepatic A-V difference to its resting level was delayed for twenty minutes or longer.

On the assumption that the splanchnic oxygen uptake of these patients was normal at rest and did not change during exercise, it has been deduced that the hepatic blood flow of the patients with a normal response of cardiac output to exercise was almost normal at rest and on exercise 
was reduced to 65 per cent of the normal resting value. In patients in whom the response of the cardiac output to exercise was severely impaired, the hepatic blood flow at rest was only 54 per cent of the resting blood flow of normal subjects and on exercise it was reduced to 27 per cent of the normal resting flow.

The very low oxygen saturation of hepatic venous blood observed during relatively light exercise in patients with severe heart disease may be concerned in the development of cardiac cirrhosis of the liver.

\section{ACKNOWLEDGMENTS}

Grateful acknowledgment is made to Mr. A. C. Pincock and Mr. R. J. Mills for skilled technical assistance. Staff Nurse I. Gibbon also gave invaluable help. We are greatly indebted to grants from the Endowment Research Fund of the United Birmingham Hospitals.

\section{REFERENCES}

1. Donald, K. W., Bishop, J. M., and Wade, O. L., A study of minute to minute changes of arteriovenous oxygen content difference, oxygen uptake and cardiac output and rate of achievement of a steady state during exercise in rheumatic heart disease. J. Clin. Invest., 1954, 33, 1146.

2. Donald, K. W., Bishop, J. M., Cumming, G., and Wade, $O$. L., The effect of exercise on the cardiac output and circulatory dynamics of normal subjects. Clin. Sc., 1955, 14, 37.
3. Bradley, S. E., Clinical aspects of hepatic vascular physiology in Transactions of the Conference on Liver Injury. Josiah Macy, Jr., Foundation, 1950, 9, 71.

4. Wade, O. L., Bishop, J. M., Cumming, G., and Donald, $K$. W., A method for the rapid estimation of the percentage oxygen saturation and oxygen content of blood. Brit. M. J., 1953, 2, 902.

5. Bradley, S. E., Ingelfinger, F. J., and Bradley, G. P., Hepatic circulation in cirrhosis of the liver. Circulation, 1952, 5, 419.

6. Myers, J. D., Brannon, E. S., and Holland, B. C., Correlative study of the cardiac output and the hepatic circulation in hyperthyroidism. J. Clin. Invest., 1950, 29, 1069.

7. Myers, J. D., and Hickam, J. B., An estimation of the hepatic blood flow and splanchnic oxygen consumption in heart failure. J. Clin. Invest., 1948, 27,620 .

8. Barcroft, J., and Florey, H., The effects of exercise on the vascular conditions in the spleen and the colon. J. Physiol., 1929, 68, 181.

9. Herrick, J. F., Grindley, J. H., Baldes, E. J., and Mann, F. C., Effect of exercise on the blood flow in the superior mesenteric, renal and common iliac arteries. Am. J. Physiol., 1940, 128, 338.

10. Barcroft, H., and Loughridge, W. M., On the accuracy of the thermostromuhr method for measuring blood flow. J. Physiol., 1938, 93, 382.

11. Bradley, S. E., Effect of posture and exercise upon blood flow through the liver in Transactions of the Conference on Liver Injury, Josiah Macy, Jr., Foundation, 1948, 7, 53.

12. Büchner, F., Klin. Wschr., 1942, 21, 721. Cited Himsworth, H. P., Lectures on the liver and its diseases. Oxford, Blackwell, 1950. 